\title{
Repeat courses of intravenous alefacept in patients with chronic plaque psoriasis provide consistent safety and efficacy
}

\author{
Nick J. Lowe, MD, John Gonzalez, MD, Jerry Bagel, MD, Ivor Caro, MD, Charles N. Ellis, MD, \\ and Alan Menter, MD
}

From Clinical Research Specialists, Santa Monica, California, Sylvana Research, San Antonio, Texas, Psoriasis Treatment Center of Central New Jersey, East Windsor, New Jersey, Massachusetts General Hospital and Harvard Medical School, Boston, Massachusetts, University of Michigan Medical School, Ann Arbor, Michigan, and Baylor University Medical Center, Dallas, Texas

\section{Correspondence}

Nick J. Lowe, MD

2001 Santa Monica Boulevard

Suite 490W

Santa Monica, CA 90404

E-mail: nlowecrs@aol.com

Drug name

alefacept: Amevive ${ }^{\circledR}$

\begin{abstract}
Background Psoriasis is a chronic, relapsing skin disease that may require multiple treatment courses. Alefacept targets the memory $T$ cells implicated in psoriasis pathogenesis. This openlabel study evaluated the safety and tolerability, efficacy, and pharmacodynamics of repeat courses of alefacept in men and women with chronic plaque psoriasis. This article reports the interim results of this ongoing study.

Methods Patients $(n=174)$ who participated in previous phase II studies of alefacept were included in this retreatment study. Intravenous alefacept $(7.5 \mathrm{mg})$ was administered once weekly for 12 weeks followed by 12 weeks of observation. Initial and subsequent retreatment courses were only given when, in the opinion of the investigators, disease had returned and necessitated treatment; CD4 ${ }^{+} \mathrm{T}$-cell counts had to be at or above the lower limit of normal.

Results Adverse events were similar regardless of the retreatment course. No opportunistic infections, rebound of disease, or flares were reported. Low titers of anti-alefacept antibodies occurred in a few patients without related safety issues. Sixty-six per cent of patients achieved $a \geq 50 \%$ reduction in the Psoriasis Area and Severity Index (PASI) at any time after the first dose of retreatment course 1. Patients who received two retreatment courses $(n=50)$ had consistent or improved responses after the second course; $64 \%$ and $68 \%$ of these patients achieved a $\geq 50 \%$ PASI improvement at any time after the first dose of retreatment courses 1 and 2 , respectively. Alefacept selectively reduced memory $T$ cells without cumulative effects.

Conclusions Repeat courses of alefacept were well tolerated, and subsequent retreatment courses were at least as effective as the initial course of therapy.
\end{abstract}

\section{Introduction}

Psoriasis is a chronic, relapsing skin disease that affects approximately 5.I million individuals in Europe and more than 7 million in the USA. ${ }^{\mathrm{I}, 2}$ The National Psoriasis Foundation estimates that between $\$$ I.6 and $\$ 3.2$ billion is spent each year in the USA on psoriasis treatments alone, and that the disease results in an annual loss of 56 million hours of work. ${ }^{3}$ This significant economic burden is accompanied by reductions in the quality of life. ${ }^{4}$ Individuals with psoriasis frequently experience physical symptoms (e.g. scaling, itching, skin redness), psychosocial problems (e.g. interacting with peers and family), and difficulty performing routine activities (e.g. exercising, sleeping, sexual activities). Nearly $80 \%$ of persons with severe psoriasis are negatively affected by their disease. $^{4}$

Psoriasis is now recognized as an immune-mediated disease in which memory effector $\left(\mathrm{CD}_{45} \mathrm{RO}^{+}\right) \mathrm{T}$ cells play a critical targets this T-cell subset. It is a fully human fusion protein consisting of the first extracellular domain of lymphocyte function-associated antigen-3 (LFA- 3 ) fused to the hinge, $\mathrm{C}_{\mathrm{H}} 2$, and $\mathrm{C}_{\mathrm{H}} 3$ sequences of $\mathrm{IgG}_{\mathrm{r}}$. LFA- 3 is a cell surface receptor found on immune accessory cells (e.g. natural killer cells, macrophages). The LFA-3 portion of alefacept binds to the $\mathrm{CD} 2$ receptor on $\mathrm{T}$ cells, thereby blocking their natural interaction with LFA- 3 on antigen-presenting cells and thus inhibiting the antigen-dependent activation of $\mathrm{T}$ cells. ${ }^{7}$ Alefacept also engages Fc $\gamma$ RIII receptors on accessory cells. ${ }^{8}$ Because CD2 expression is higher on memory than on naive $\left(\mathrm{CD}_{45} \mathrm{RA}^{+}\right) \mathrm{T}$ cells, ${ }^{9,10}$ alefacept produces a selective apoptotic reduction in memory $\mathrm{T}$ cells. ${ }^{\text {II }}$

As previously reported, a single course of intravenous alefacept was well tolerated and significantly improved psoriasis, with sustained clinical benefit after cessation of therapy. ${ }^{\text {II }}$ Because of the long-lasting, relapsing nature of psoriasis, it is important to study the effects of repeat courses of alefacept. The primary objective of this study was to determine the 
safety and tolerability of repeat courses of intravenous alefacept in men and women with chronic plaque psoriasis who participated in previous phase II studies of alefacept. Efficacy and pharmacodynamic effects were secondary objectives. This article reports the interim results of this ongoing study.

\section{Methods}

\section{Patients}

Men and women with chronic plaque psoriasis who participated in previous phase II studies of alefacept were eligible for this retreatment study. Patients were eligible for the phase II studies if they had chronic plaque psoriasis that involved $\geq 10 \%$ of the body surface area which was diagnosed at least 12 months before study entry, were receiving systemic treatment or phototherapy or were candidates for such treatment, and had no serious hepatic or renal disease, history of cancer (basal cell carcinoma or less than three squamous cell carcinomas of the skin were permitted), or serious infection within the previous 3 months. Patients had to complete the 12-week treatment and observation phases of the phase II studies before being considered for the retreatment study.

Patients were not eligible for retreatment courses until their disease had returned to a level at which the investigator judged that systemic therapy or phototherapy was required. Alefacept treatment could only be started when CD4 ${ }^{+} \mathrm{T}$-cell counts were at or above the lower limit of normal. The retreatment study was conducted in accordance with the Declaration of Helsinki, and all patients provided written informed consent before enrolment. The local institutional review board at each participating site approved the protocol.

\section{Study design}

In the previous phase II studies, patients received one or two courses of alefacept or one course of placebo. A treatment course was defined as 12 weeks of once-weekly treatment followed by 12 weeks of observation. A wide range of doses were studied: $0.025-0.75 \mathrm{mg} / \mathrm{kg}$ intravenously, $0.15-0.375 \mathrm{mg} / \mathrm{kg}$ intramuscularly, and $0.15-0.75 \mathrm{mg} / \mathrm{kg}$ subcutaneously.

In the ongoing, open-label, multicenter (18 US centers) retreatment study, eligible patients received alefacept $(7.5 \mathrm{mg})$ once weekly as a 30-s intravenous bolus for a treatment period of 12 weeks. A minimum 12-week washout period was required after each treatment course; thereafter, patients could be considered for a subsequent retreatment course if needed. In the retreatment courses, alefacept dosing was halved in patients with absolute $\mathrm{CD}^{+}{ }^{+} \mathrm{T}$-cell counts of $<300$ cells $/ \mu \mathrm{L}$ and withheld in patients with absolute CD4 ${ }^{+} \mathrm{T}$-cell counts of $<200$ cells $/ \mu \mathrm{L}$. Dosing was withheld for 2 weeks when fever or evidence of clinically significant infection was present. Alefacept was permanently discontinued if $\mathrm{CD} 4^{+}$ T-cell counts were $<200$ cells $/ \mu \mathrm{L}$ on four consecutive visits.

Patients returned to the clinic for safety, tolerability, efficacy, and pharmacodynamic evaluations weekly during each treatment phase, at 2, 4, 6, 8, and 12 weeks during the follow-up phase of the first retreatment course, and at 2, 6, and 12 weeks during the follow-up phases of subsequent retreatment courses. Whenever possible, final evaluations were performed on patients who withdrew early.

\section{Concomitant medications}

Before receiving the initial and subsequent retreatment courses, patients observed a 2-week washout period from treatment with moderate-potency topical corticosteroids, vitamin D analogs, topical retinoids, keratolytics, and coal tar (other than on the groin, scalp, palms, and soles). Moreover, a 4-week washout period from treatment with other investigational agents, systemic psoriasis therapies, high-potency topical corticosteroids, and phototherapy was required.

Moderate-potency topical corticosteroids, vitamin D analogs, topical retinoids, keratolytics, and coal tar could be used throughout the retreatment study on the groin, scalp, palms, and soles only. Low-potency topical corticosteroid use was permitted, if necessary, but not within $12 \mathrm{~h}$ of efficacy evaluations. Patients were not permitted to receive systemic psoriasis therapies, high-potency topical corticosteroids, or phototherapy at any time during the retreatment study.

\section{Safety and tolerability assessments}

All adverse events reported by the patient or observed by study personnel were recorded throughout the retreatment study. Medical histories, physical examinations, vital signs, blood chemistries (sodium, potassium, chloride, bicarbonate, blood urea nitrogen, creatinine, calcium, phosphate, albumin, total protein, alkaline phosphatase, total bilirubin, alanine aminotransferase, aspartate aminotransferase, and gamma glutamyl transaminase), complete blood counts (with differential and platelet count), and urinalyses were performed at various times throughout the retreatment study. Patients were also monitored for the possible development of anti-alefacept antibodies through the collection of whole blood at baseline (retreatment course 1 only) and at 6 and 12 weeks during the follow-up phase of each retreatment course. Anti-alefacept antibody analyses were performed at Biogen, Inc. (Cambridge, MA, USA). All other laboratory tests were performed at Covance Central Laboratory Services, Inc. (Indianapolis, IN, USA).

\section{Efficacy assessments}

The Psoriasis Area and Severity Index (PASI) and Physician Global Assessment (PGA) were used to measure disease severity. PASI scores, which range from 0 (no psoriasis) to 72 (the most severe disease possible), combine assessments of the extent of the body surface area affected and the degree of erythema, induration, and desquamation. ${ }^{12}$ For PGA, a seven-point scale rating disease severity as "clear", "almost clear", "mild", "mild to moderate", "moderate", "moderate to severe", or "severe" was used. In retreatment course 1, PASI and PGA evaluations were performed before treatment, at $3,5,7,9,11$, and 12 weeks during 
treatment, and at all follow-up visits. In subsequent retreatment courses, these evaluations were performed before treatment, at 7 weeks during treatment, and at 2 and 12 weeks during follow-up. In each retreatment course, efficacy endpoints included the percentage of patients who achieved $a \geq 75 \%$ PASI reduction from baseline (defined as the baseline of retreatment course 1), a $\geq 50 \%$ PASI reduction from baseline, and PGA of "clear" or "almost clear" at 2 weeks after treatment cessation (primary endpoint). Given that disease clearance with alefacept continues beyond the treatment period, ${ }^{11}$ efficacy endpoints were also measured at any time after the first dose of alefacept (hereafter referred to as the overall response rates).

\section{Pharmacodynamic assessments}

Total lymphocyte counts, $\mathrm{CD} 4^{+}$and $\mathrm{CD}^{+} \mathrm{T}$ cells, $\mathrm{CD} 4^{+}$and $\mathrm{CD} 8^{+}$ memory and naive T cells, CD16 $/ \mathrm{CD}^{+} 6^{+}$natural killer cells, and CD19 ${ }^{+} \mathrm{B}$ cells were determined from blood samples obtained at all study visits (except at 4 weeks after treatment cessation in retreatment course 1). Analyses were performed by Covance Central Laboratory Services, Inc.

\section{Results}

\section{Disposition and baseline characteristics}

Patients who entered the retreatment study had received either alefacept $(n=\mathrm{I} 44)$ or placebo $(n=30)$ in previous phase II studies. Of these patients, I74, I07, and 23 have thus far received at least one dose of alefacept during retreatment courses I, 2, and 3, respectively. All patients were included in the safety analyses. The majority of patients in each course received all I 2 doses of study drug $(67 \%$ and $62 \%$ for retreatment courses I and 2, respectively); no patient has completed retreatment course 3 to date. Only two patients permanently discontinued because of low $\mathrm{CD}_{4}^{+} \mathrm{T}$-cell counts (see "Safety and tolerability" section). Only patients who completed the
I2-week follow-up phase of a course or withdrew from the study were included in the efficacy and pharmacodynamic analyses; at this time, I70 patients are evaluable in retreatment course $\mathrm{I}$, and 50 patients are evaluable in retreatment courses I and 2.

The mean age of the patients enrolled in this study was 45 years; $66 \%$ were male, and $84 \%$ were white. Patients had a mean weight of $95 \mathrm{~kg}$ and a mean height of $\mathrm{I} 73 \mathrm{~cm}$. At baseline, the median body surface area involvement of psoriasis ranged from $\mathrm{I} 9 \%$ to $2 \mathrm{I} \%$ in the three retreatment courses, and the median PASI score ranged from 9.9 to I 3.3 . The baseline PGA was "moderate" or "moderate to severe" in $78 \%, 61 \%$, and $57 \%$ of patients during retreatment courses I, 2, and 3, respectively.

\section{Safety and tolerability}

Repeat courses of alefacept were similarly well tolerated. The most common adverse events were pharyngitis ( $13 \%)$ and rhinitis $\left(\mathrm{I}_{3} \%\right)$ in retreatment course $\mathrm{I}$, and infection $(7 \%)$ and pharyngitis $(7 \%)$ in retreatment course 2 (Table I). The common cold was the most frequent event coded to "infection". There were no complicated or opportunistic infections. Rebound of disease or flare did not occur after completion of either retreatment course I or 2. No serious, drug-related adverse events were reported throughout the study.

Discontinuation rates because of adverse events were low $(<2 \%)$ in retreatment courses I and 2 . Adverse events resulted in the discontinuation of three patients from retreatment course I (two for low $\mathrm{CD}_{4}{ }^{+} \mathrm{T}$-cell counts, one for pneumonia) and two patients from retreatment course 2 (one for herpes zoster, one for pulmonary fibrosis). The herpes zoster and pneumonia resolved with conventional treatment. The pulmonary fibrosis persisted. Because of low $\mathrm{CD}_{4}^{+} \mathrm{T}$-cell counts, one patient was withdrawn after receiving two doses of alefacept $(7.5 \mathrm{mg})$ and one dose of alefacept $(3.75 \mathrm{mg})$; the

\begin{tabular}{|c|c|c|c|}
\hline & Retreatment course 1 & Retreatment course 2 & Retreatment course 3 \\
\hline Adverse event & $n(\%)$ & $n(\%)$ & $n(\%)$ \\
\hline Pharyngitis & $23(13)$ & $8(7)$ & 0 \\
\hline Rhinitis & $22(13)$ & $7(7)$ & 0 \\
\hline Accidental injury & $19(11)$ & $6(6)$ & 0 \\
\hline Viral infection & $18(10)$ & $7(7)$ & $2(9)$ \\
\hline Flu syndrome & $15(9)$ & $3(3)$ & 0 \\
\hline Headache & $15(9)$ & $5(5)$ & 0 \\
\hline Pain & $13(7)$ & $7(7)$ & $1(4)$ \\
\hline Infection & $9(5)$ & $8(7)$ & 0 \\
\hline Nausea & $9(5)$ & $2(2)$ & 0 \\
\hline Pruritus & $8(5)$ & $1(<1)$ & 0 \\
\hline Sinusitis & $6(3)$ & $6(6)$ & 0 \\
\hline
\end{tabular}

Table 1 Adverse events reported in $\geq 5 \%$ of patients in any retreatment course

Total number of patients completing retreatment courses I, 2, and 3 are I74, I07, and 23 , respectively. 
lower dose of alefacept was administered because of low $\mathrm{CD}_{4}{ }^{+} \mathrm{T}$-cell counts. The patient's $\mathrm{CD}_{4}{ }^{+} \mathrm{T}$-cell counts were 259 cells $/ \mu \mathrm{L}$ at screening, 478 cells $/ \mu \mathrm{L}$ before dosing, 333 cells $/ \mu \mathrm{L}$ at the time of the first dose, and $\mathrm{I} 53$ cells $/ \mu \mathrm{L}$ at the time of the $3.75-\mathrm{mg}$ dose. A count of 280 cells $/ \mu \mathrm{L}$ was reported at the last available follow-up visit. The other patient withdrawn for low $\mathrm{CD}_{4}{ }^{+} \mathrm{T}$-cell counts had a normal count at screening $(624$ cells $/ \mu \mathrm{L})$, but counts of $<200$ cells $/ \mu \mathrm{L}$ were associated with each of the first four alefacept injections, prompting the withdrawal of the patient. The patient's $\mathrm{CD}_{4}^{+}$ T-cell count was $\mathrm{I} 90$ cells $/ \mu \mathrm{L}$ at the last available follow-up visit. In both cases of low $\mathrm{CD}_{4}^{+} \mathrm{T}$-cell counts, there were no accompanying adverse events of note.

Five patients had malignancies diagnosed during the study. One 65 -year-old woman with a family history of colon cancer and a recent medical history of guaiac-positive stools was diagnosed with adenocarcinoma of the colon. A 66-year-old man with a history of heavy smoking was diagnosed with adenocarcinoma of the lung. Three patients with long-standing psoriasis (I9-34 years) and previous exposure to psoralen plus ultraviolet A (PUVA) and methotrexate were diagnosed with squamous cell carcinoma of the skin. All five patients received appropriate surgery and treatment.

There were no clinically important trends in medical history or physical examination findings, vital signs, or standard laboratory test results. Of the $I 74$ patients dosed in retreatment course I, three (I.7\%) tested positive for anti-alefacept antibodies after treatment initiation, one of whom tested positive before dosing. Two patients tested positive before dosing in retreatment course $\mathrm{I}$, but did not have a positive result after the start of therapy. Of the I07 patients dosed in retreatment course 2 , one $(<\mathrm{I} \%)$ tested positive after beginning therapy. In all cases, titers were low and there was no association with safety issues.

\section{Efficacy}

In the previous phase II studies, alefacept significantly improved psoriasis symptoms. Alefacept had a consistent efficacy profile during repeat courses. Maximum mean reductions from baseline PASI were $5 \mathrm{I} \%$ at 6 weeks after the last dose of retreatment course I, and $47 \%$ at 2 weeks after the last dose of retreatment course 2 (Fig. I). Retreatment course 2 baseline was lower relative to the baseline of retreatment course I (by approximately $30 \%$ ), suggesting that patients who entered the second retreatment course of therapy had retained some clinical improvement from the first retreatment course. In retreatment course I, overall response rates for patients achieving a PGA of "clear" or "almost clear", a $\geq 75 \%$ PASI reduction, and $a \geq 50 \%$ PASI reduction were $29 \%, 39 \%$, and $66 \%$, respectively (Fig. 2a). Of the 50 patients who received two consecutive retreatment courses of alefacept, the percentage of patients who responded during the second course was consistent with or better than that

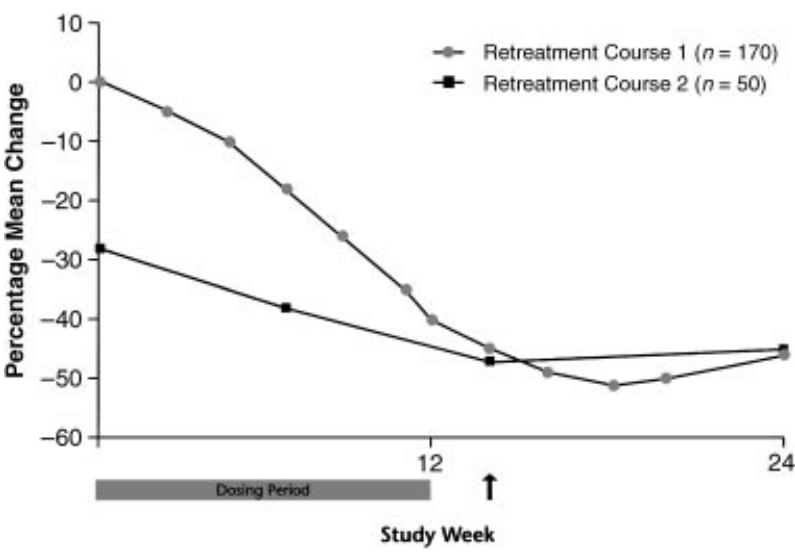

Figure 1 Mean percentage reductions from the baseline Psoriasis Area and Severity Index during repeat courses of intravenous alefacept. The arrow indicates 2 weeks after the last dose of treatment, the primary endpoint
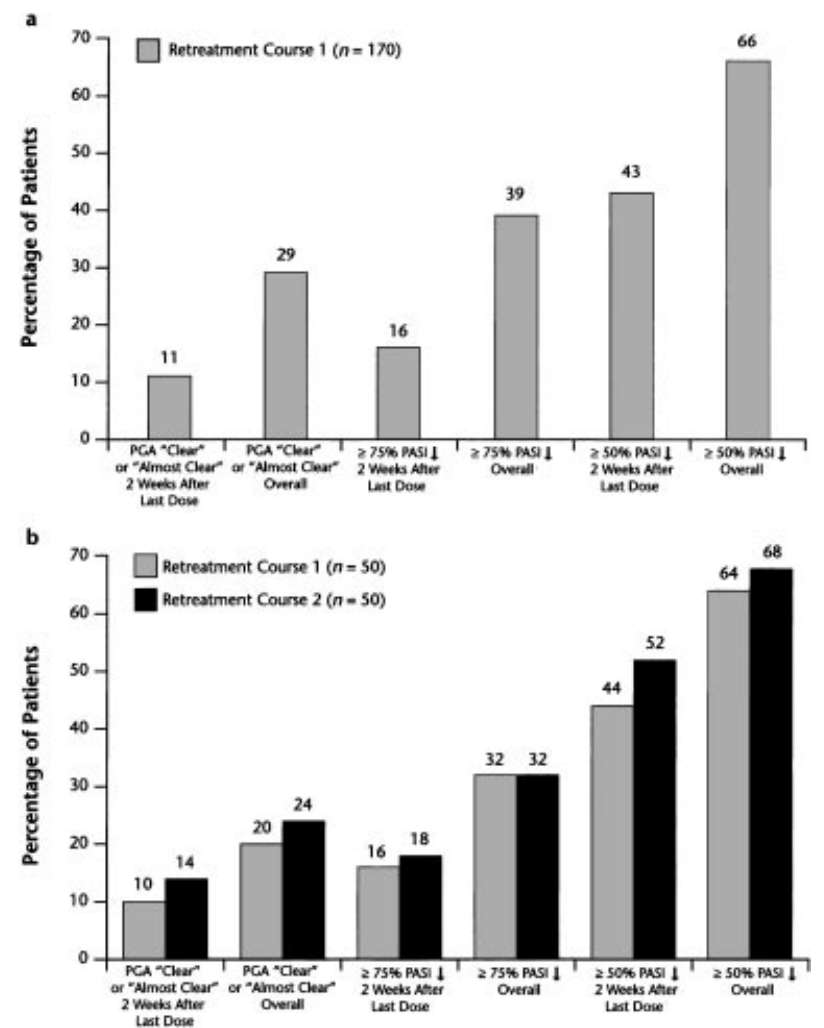

Figure 2 Physician Global Assessment (PGA) of “clear” or "almost clear" and reductions in the Psoriasis Area and Severity Index (PASI) of $\geq 50 \%$ and $\geq 75 \%$ in patients retreated with intravenous alefacept during retreatment course I (a) and in patients who received two retreatment courses (b). The bars indicate the percentage of patients who achieved various degrees of improvement. In (b), only the 50 patients who completed both retreatment courses are included. The primary study endpoint was 2 weeks after the last dose and the overall response rate was defined as the response any time after the first dose of study drug 


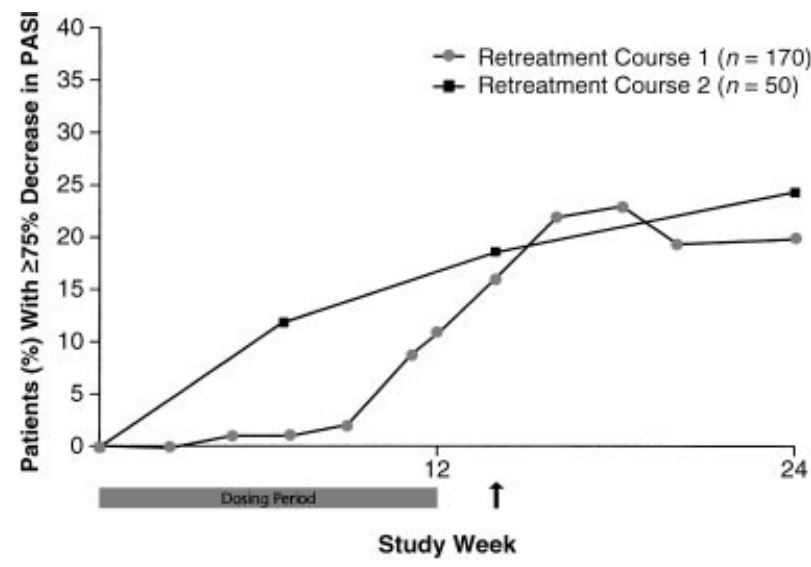

Figure 3 Percentage of patients who achieved a $\geq 75 \%$ reduction from baseline in the Psoriasis Area and Severity Index (PASI) during repeat courses of intravenous alefacept. The arrow indicates 2 weeks after the last dose of treatment, the primary endpoint

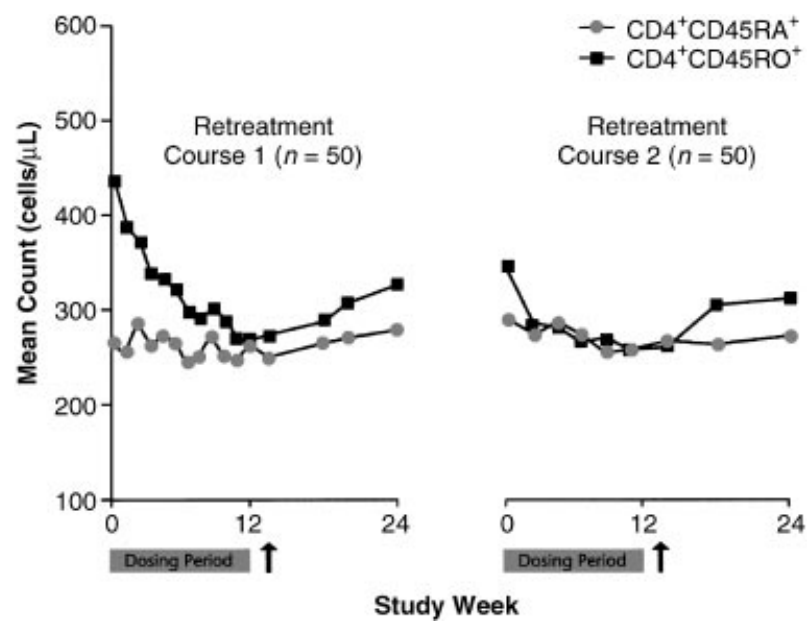

Figure 4 Mean changes in memory $\left(\mathrm{CD}_{4}{ }^{+} \mathrm{CD}_{4} \mathrm{RO}^{+}\right)$and naive $\left(\mathrm{CD}_{4}{ }^{+} \mathrm{CD}_{45} \mathrm{RA}^{+}\right) \mathrm{T}$-cell counts during repeat courses of intravenous alefacept. Results are shown for the 50 patients who received two retreatment courses of alefacept. The arrow indicates 2 weeks after the last dose of treatment, the primary endpoint

observed during the first course (Fig. 2b). In both retreatment courses, patients continued to improve after the dosing interval. A higher percentage of patients had $\mathrm{a} \geq 75 \%$ decrease in PASI at I 2 weeks post-dosing than at any time during the dosing interval or 2 weeks after the last dose (primary endpoint) (Fig. 3).

\section{Pharmacodynamics}

Alefacept reduced total lymphocyte and lymphocyte subset counts to a similar extent over both retreatment courses. Figure 4 demonstrates the selectivity of alefacept for $\mathrm{CD}_{4}^{+}$ memory $\mathrm{T}$ cells vs. $\mathrm{CD}_{4}^{+}$naive $\mathrm{T}$ cells over retreatment courses I and 2. Similar results were observed for $\mathrm{CD} 8^{+} \mathrm{T}$-cell subsets. The mean $\mathrm{CD}_{4}{ }^{+} \mathrm{T}$-cell count at $T_{\max }$ was $454 \mathrm{cells} / \mu \mathrm{L}$ $(-43 \%$ relative to retreatment course I baseline) in retreatment course I and 469 cells $/ \mu \mathrm{L}(-4 \mathrm{I} \%$ relative to retreatment course I baseline) in retreatment course 2. Corresponding results for $\mathrm{CD}^{+} \mathrm{T}$ cells were $2 \mathrm{I} 4$ cells $/ \mu \mathrm{L}(-49 \%)$ and $2 \mathrm{I} 4$ cells $/ \mu \mathrm{L}(-48 \%)$. There were no notable changes in $\mathrm{CD}_{1} 6^{+} / \mathrm{CD}_{5} 6^{+}$natural killer cells or $\mathrm{CD}_{1} 9^{+} \mathrm{B}$ cells throughout the study. Ninety-eight per cent of patients had total lymphocyte counts at or above the lower limit of normal at 12 weeks after the last dose, regardless of retreatment course; $94 \%$ and $92 \%$ of patients had $\mathrm{CD}_{4}{ }^{+} \mathrm{T}$-cell counts at or above the lower limit of normal at I 2 weeks after the last dose of retreatment courses I and 2, respectively.

\section{Discussion}

Psoriasis is a chronic disease with, as yet, no cure. Treatments are available to reduce or suppress the symptoms, but do not provide long-lasting disease remission. Currently available agents for psoriasis are generally efficacious, but safety, tolerability, and the need for regular laboratory or other evaluations are often a concern. Cyclosporine is nephrotoxic, particularly with long-term use, ${ }^{13}$ while methotrexate is associated with bone marrow toxicity during short-term use and hepatotoxicity during extended use. ${ }^{\mathrm{I}}$ Both of these agents can also interact with a variety of drugs, thereby increasing the potential for toxicity. ${ }^{15}$ Retinoids are teratogenic, invariably produce mucocutaneous side-effects, and are less efficacious than cyclosporine or methotrexate. ${ }^{16}$ PUVA use is associated with a dose-related increase in the risk of squamous cell carcinoma ${ }^{17}$ and possibly melanoma. ${ }^{18}$ These data underscore the need for safer and better tolerated, longer term psoriasis therapies, thus benefiting a patient's quality of life.

Alefacept was well tolerated when used in repeat I2-week courses for the treatment of chronic plaque psoriasis. The most common adverse events in this retreatment study were pharyngitis, rhinitis, and infection, which was most commonly associated with a cold. No opportunistic infections, rebound of disease, or flares were reported. The patient in whom lung fibrosis was diagnosed had a 24 -year history of coal dust exposure and a history of pneumonia, both of which were thought to have contributed to the fibrosis. The patient also had a significant smoking history. Five cases of malignancy (two systemic, three skin) were reported in the study; in each case, there were additional risk factors that probably contributed to the occurrence. In addition, the incidence of these cancers is similar to that expected in untreated individuals of the same age. A total of 22 patients of at least 60 years of age were enrolled in this study, and the incidences of colon and lung cancer in this age group are approximately $I$ in 25 and $\mathrm{I}$ in $\mathrm{I} 6$, respectively. ${ }^{\mathrm{I}}$

Consistent with its fully human protein composition, the immunogenicity of alefacept was very low. 
Although this was an open-label study, the efficacy results of the first retreatment course, with overall response rates of $39 \%$ for patients achieving $a \geq 75 \%$ reduction in PASI from baseline and $66 \%$ with $\mathrm{a} \geq 50 \%$ reduction, are consistent with those of a previous randomized, placebo-controlled, double-blind study. ${ }^{\text {II }}$ The overall response rates as defined in this study are likely to be more important to patients and physicians in clinical practice compared with response rates measured at a single time point. Alefacept provided consistent clinical benefit following one or more retreatment courses. Patients had either an equivalent clinical response or further improvement after a second retreatment course. Efficacy increased over time in both retreatment courses. There was no evidence of tachyphylaxis.

Patients entering the second retreatment course had a lower disease burden relative to those entering the first retreatment course, as suggested by the $30 \%$ lower mean baseline PASI score, indicating a sustained treatment benefit. The results support those of a previous study suggesting that alefacept is a remittive rather than suppressive therapy. ${ }^{I}{ }^{I}$ Remittive therapies have the advantage of increasing the time a patient is off medication and allowing for more disease-free living. PUVA and Goeckerman therapy are the only remittive therapies currently available $;^{20-22}$ however, as mentioned previously, PUVA is associated with safety concerns, especially with longterm use; in addition, Goeckerman therapy is extremely time intensive for both the patient and physician and may require three or more weeks of daily, day-long sessions to induce remission. $^{22}$

As seen in other clinical studies, ${ }^{\text {II }}$ alefacept selectively reduced memory $\mathrm{T}$ cells, with relative sparing of naive $\mathrm{T}$ cells. The mechanistic basis for this specificity involves at least two factors: the level of $\mathrm{CD}_{2}$ expression and the rate of replenishment of the different subpopulations. Memory $\mathrm{T}$ cells have higher $\mathrm{CD}_{2}$ expression relative to naive T cells. ${ }^{9}$, ro Both memory and naive $\mathrm{T}$ cells can regenerate, but the absolute rate of replenishment ( $>10^{8}-10^{9}$ cells/day) is greater for naive $\mathrm{T}$ cells because of daily production by the thymus. ${ }^{23}$ Over the multiple retreatment courses, a cumulative effect on lymphocytes or lymphocyte subsets was not observed. Nadirs and rates of recovery were similar with repeat dosing. A correlation between the extent of reduction in memory $\mathrm{T}$ cells and clinical response has previously been demonstrated, ${ }^{\text {II }}$ supporting the belief that this T-cell population contains the clonal precursors that drive psoriasis disease activity. $^{6,24}$

Maintaining excellent safety, tolerability, and efficacy over multiple courses of treatment is important because of the chronic and relapsing nature of psoriasis. Intravenous alefacept was well tolerated and had a consistent safety and tolerability profile during repeat courses. The clinical response to alefacept was consistent amongst patients who received two retreatment courses, with a trend for additional benefit in retreatment course 2 . Repeat courses of alefacept selectively reduced memory $\mathrm{T}$ cells without cumulative effects.

\section{Acknowledgments}

This study was funded by Biogen, Inc., Cambridge, MA, USA.

A patent on the use of alefacept for the treatment of psoriasis has been assigned to Biogen and the University of Michigan. None of the authors have a financial interest in the patent.

Drs N.J. Lowe, C.N. Ellis, and A. Menter are consultants to Biogen, as well as to other companies that have and are developing treatments for psoriasis.

Principal investigators: Debra Breneman, MD (Cincinnati, $\mathrm{OH}$ ); Marc Epstein, DO (Tucson, AZ); Harold Farber, MD (Philadelphia, PA); Linda Ford, MD (Papillon NE); William T. Garland, MD (Lawrenceville, NJ); Michael Gold, MD (Nashville, TN); Frank Hampel, MD (New Braunfels, TX); Gerald G. Krueger, MD (Salt Lake City, UT); Debra Liu, MD (Winston-Salem, NC); Anjuli Nayak, MD (Normal, IL); Lawrence C. Parish, MD (Philadelphia, PA); Jerold Powers, MD (Scottsdale, AZ); Ronald Savin, MD (New Haven, CT); and Donna Zeide, MD (West Palm Beach, FL).

\section{References}

I Christophers E. Psoriasis - epidemiology and clinical spectrum. Clin Exp Dermatol 200I; 26: 3 I4-320.

2 Koo J. Population-based epidemiologic study of psoriasis with emphasis on quality of life assessment. Dermatol Clin I996; I4: 485-496.

3 National Psoriasis Foundation. About psoriasis. Available at http://www.psoriasis.org. Accessed April 2002.

4 Krueger G, Koo J, Lebwohl M, et al. The impact of psoriasis on quality of life: results of a I 998 National Psoriasis Foundation patient-membership survey. Arch Dermatol 200I; 137: 280-284.

5 Barker JN. Psoriasis as a T cell-mediated autoimmune disease. Hosp Med i998; 59: 530-533.

6 Robert C, Kupper TS. Inflammatory skin diseases, T cells, and immune surveillance. N Engl J Med I999; 34I: I 8 I 7-I 828 .

7 Miller GT, Hochman PS, Meier W, et al. Specific interaction of lymphocyte function-associated antigen 3 with CD2 can inhibit T cell responses. J Exp Med I993; I78: 2 II-222.

8 Majeau GR, Meier W, Jimmo B, et al. Mechanism of lymphocyte function-associated molecule $3-\mathrm{Ig}$ fusion proteins inhibition of $\mathrm{T}$ cell responses: structure/function analysis in vitro and in human $\mathrm{CD}_{2}$ transgenic mice. $J$ Immunol I994; I52: 2753-2767.

9 Sanders ME, Makgoba MW, Sharrow SO, et al. Human memory $\mathrm{T}$ lymphocytes express increased levels of three cell adhesion molecules (LFA-3, CD 2, and LFA-I) and three other molecules (UCHLI, CDw29, and Pgp-I) and 
have enhanced IFN- $\gamma$ production. J Immunol I988; I40: I40I-I 407 .

Io Majeau GR, Whitty A, Yim K, et al. Low affinity binding of an $\mathrm{LFA}_{-3} / \mathrm{IgG}_{\mathrm{I}}$ fusion protein to $\mathrm{CD}_{2}{ }^{+} \mathrm{T}$ cells is independent of cell activation. Cell Adhes Commun I999; 7: 267-279.

I I Ellis CN, Krueger GG for the Alefacept Clinical Study Group. Treatment of chronic plaque psoriasis by selective targeting of memory effector T lymphocytes. N Engl J Med 200I; 345: 248-255.

I 2 Fredriksson T, Pettersson U. Severe psoriasis - oral therapy with a new retinoid. Dermatologica I978; I 57: 238-244.

I 3 Lim KK, Su WP, Schroeter AL, et al. Cyclosporine in the treatment of dermatologic disease: an update. Mayo Clin Proc I996; 7I: II 82-II9I.

I4 Boffa MJ, Chalmers RJ. Methotrexate for psoriasis. Clin Exp Dermatol I996; 2I: 399-408.

I 5 Lebwohl M, Ali S. Treatment of psoriasis. Part 2. Systemic therapies. J Am Acad Dermatol 200I; 45: 649-66I.

I6 DiGiovanna JJ. Systemic retinoid therapy. Dermatol Clin 200I; I9: I6I-I67.

I7 Stern RS, Liebman EJ, Väkevä L. Oral psoralen and ultraviolet-A light (PUVA) treatment of psoriasis and persistent risk of nonmelanoma skin cancer. J Natl Cancer Inst I 998; 90: I 278-I 284 .

I 8 Stern RS. The risk of melanoma in association with longterm exposure to PUVA. J Am Acad Dermatol 200I; 44: $755-761$.

I9 American Cancer Society. Cancer Facts and Figures 2002. Atlanta, GA: American Cancer Society, 2002.

20 Spuls PI, Witkamp L, Bossuyt PM, Bos JD. A systematic review of five systemic treatments for severe psoriasis. $\mathrm{Br} J$ Dermatol I997; I37: 943-949.

2 I Koo J, Lebwohl M. Duration of remission of psoriasis therapies. J Am Acad Dermatol I999; 4I: 5I-59.

22 Menter A, Cram DL. The Goeckerman regimen in two psoriasis day care centers. J Am Acad Dermatol I983; 9: 59-65.

23 Haynes BF, Markert ML, Sempowski GD, et al. The role of the thymus in immune reconstitution in aging, bone marrow transplantation, and HIV-I infection. Annu Rev Immunol 2000; I 8: 529-560.

24 Fuhlbrigge RC, Kieffer JD, Armerding D, Kupper TS. Cutaneous lymphocyte antigen is a specialized form of PSGL-I expressed on skin-homing T cells. Nature I997; 389: 978-98I. 